С.М. Туряниця, І.Ю. Пікіна

Державний вищий навчальний заклад «Ужгородський національний університет»

\title{
Клініко-епідеміологічні особливості спалаху дифтерії серед іноземних студентів Ужгородського національного університету
}

Зниження поствакцинального імунітету проти дифтерії у дорослих, спричиненого невиконанням ревакцинації разом із відсутністю відповідної настороженості, призвели до того, що дифтерія знов стала актуальною проблемою. У статті представлено дані щодо епідемії дифтерії 1990-х років в Україні. У цей період епідемічну ситуацію з дифтерії відзначали в усіх незалежних республіках колишнього СРСР, смертність при цьому становила 3-23\%. Дифтерія залишається ендемічною хворобою на цих територіях, а також у країнах Азії, Близького Сходу, Африки, Латинської Америки, де рівень охоплення населення щепленням за допомогою вакцин, що містять дифтерійний токсин, нижчий за оптимальний. Наведено приклад спалаху захворювання серед 15 іноземних студентів Ужгородського національного університету у жовтні 2019 р. Проаналізовано сучасний стан проблеми, наведено основні принципи контролю над спалахами дифтерії.

Ключові слова: дифтерія, спалах дифтерії, епідемія дифтерії в Україні, вакцинація проти дифтерії.

Дифтерія - гостре інфекційне захворювання з повітрянокрапельним механізмом передавання, що характеризується місцевим фібринозним запаленням (переважно слизових оболонок ротоглотки) та явищами загальної інтоксикації з переважним ураженням серцево-судинної та нервової систем, нирок (Центр громадського здоров'я МОЗ України, 2020). Зрідка дифтерія проявляється як шкірна, вагінальна, кон'юнктивальна чи вушна інфекція. Шкірну форму дифтерії відзначають у країнах із тропічним кліматом.

Збудник дифтерії - бактерії роду Corynebacterium, токсигенні штами переважно Corynebacterium diphtheriae, зрідка Corynebacterium ulcerans i Corynebacterium pseudotuberculosis (Всемирная организация здравоохранения, 2018). Це грампозитивна нерухома бацила, що не утворює спор. Вид Corynebacterium diphtheriae неоднорідний за культуральними, морфологічними і ферментативними якостями. Розрізняють 4 біовари Corynebacterium diphtheriae gravis, mitis, intermedius та belfanti. Усі вони можуть бути токсигенними і нетоксигенними. Токсигенні біовари виділяють екзотоксин, який затримує синтез білка в усіх клітинах, включаючи міокардіоцити, клітини тканини нирок і периферичні нерви, в яких порушується процес провідності. Нетоксигенні штами Corynebacterium diphtheriaе викликають ангіну, інші - інвазивні інфекції та ендокардит (American Academy of Pediatrics, 2009).

Епідемія дифтерії в Україні розпочалася в 1991 р. Ї̈̈ особливістю стало переважне ураження дорослих осіб. Так, під час епідемії 1990-х років питома вага дорослих пацієнтів у загальній структурі хворих на дифтерію становила >80\% (Nekrassova L.S. et al., 2000). Епідемія дифтерії сягнула піку у 1995 р.: захворюваність становила 10,25 на 100 тис. населення, що в 48,8 раза підвищило показник 1990 р. (Мороз Л.В., 1997). У наступні роки спостерігали тенденцію до зниження захворюваності.

Проте дифтерія залишається актуальною проблемою для України. За даними Державного закладу «Український центр з контролю та моніторингу захворювань Міністерства охорони здоров'я України», протягом 2004-2014 рр. зареєстровано 116 випадків захворювання (Анастасій І.А., 2017). Результати клітинних обстежень хворих на дифтерію, які були госпіталізовані, свідчать про незначну інтоксикацію, нормальну температуру тіла, фібринозні нальоти на мигдаликах у вигляді ніжних плівок, які легко знімалися або були відсутні. Діагноз «дифтерія» підтверджений позитивним бактеріологічним обстеженням і виділенням культури Corynebacterium diphtheriae.

Слід пам'ятати, що діагноз дифтерії - перш за все клінічний. Більшість хворих у цей період були щеплені. Клінічна діагнос- тика дифтерії в цій групі хворих становить труднощі у зв'язку з прихованим і атиповим перебігом з відсутністю нальотів на вільних поверхнях піднебінних мигдаликів. Верифікація діагнозу відбувається бактеріологічним обстеженням мазків із зіва та слизової оболонки носа. Бактеріологічне обстеження контактних осіб проводять одноразово, а у разі підозри та наявності сумнівних клінічних ознак - триразово. Виділення нетоксигенних штамів Corynebacterium diphtheriae у хворого із клінічними ознаками в ротоглотці, який перебував в осередку дифтерії, є підставою для підтвердження діагнозу «дифтерія». Серологічні методи обстеження щеплених (реакція непрямої гемаглютинації) втрачають верифікаційну інформативність. Наявність високих титрів антидифтерійних антитіл не може бути ознакою бактеріоносійства, оскільки у щеплених осіб реагування імунної системи відбувається уже на 2-гу добу після початку захворювання.

Зниження поствакцинального імунітету у дорослих, які були вакциновані в 2000 р. і в подальшому не отримували ревакцинації кожні 10 років, «допомогли» дифтерії знов стати актуальною проблемою.

У роки низької захворюваності на дифтерію виникають один або два вогнища дифтерійної інфекції, які пов'язані не з сезонністю, а з умовами спілкування людей. Нові колективи осіб юнацького віку формуються частіше восени, що зумовлює початок зростання захворюваності. Необхідно також мати на увазі, що накопичення дифтерійної інфекції в окремих колективах у вигляді носійства токсигенних штамів Corynebacterium може приводити до «прориву» імунітету і розвитку захворювань. Прикладом можуть бути спостереження за виникненням спалаху дифтерії серед іноземних студентів медичного факультету Ужгородського національного університету.

Так, протягом жовтня 2019 р. в Обласну клінічну інфекційну лікарню м. Ужгород поступили 15 іноземних студентів V курсу медичного факультету Ужгородського національного університету віком 21 рік-27 років. Перший випадок дифтерії ротоглотки, викликаної Corynebacterium diphtheriae, біоваром mitis, нетоксигенним, зареєстрований 17.10.2019 р.

Хворий С., 24 роки. Захворів раптово. Скарги на загальну слабкість, «дертя» у горлі, біль при ковтанні, головний біль, підвищення температури тіла до $38^{\circ} \mathrm{C}$. При огляді піднебіння мигдалики збільшені, на вільній поверхні - острівковий наліт, який не знімався шпателем, не кровив. При бактеріологічному обстеженні мазка з ротоглотки виділені нетоксигенні Corynebacterium diphtheriae, біовар mitis, нетоксигенний. 
3 діагнозом «дифтерія ротоглотки» госпіталізований в Обласну клінічну інфекційну лікарню м. Ужгород, де перебував 22 ліжко-дні.

Електрокардіографічне обстеження від 18.10.2019 р.: синусова тахікардія (пульс 108 уд./хв), негативний зубець $T$ у відведенні $a V F$.

Протягом 22-24.10.2019 р. у вогнищі обстежено і госпіталізовано 14 контактних осіб з аналогічними скаргами та клінічними симптомами. Бактеріологічне обстеження мазків із зіва дали позитивний результат росту Corynebacterium diphtheriae, біовар mitis, нетоксигенний. Проведене лікування цефтріаксоном, аскорбіновою кислотою, 10\% розчином глюкози. На 3-тю добу температура тіла нормалізувалася, нальоти на мигдаликах починали зменшуватись і на 7-му - зникали. Протягом захворювання в усіх хворих на електрокардіограмі мали місце порушення провідності, синусова тахікардія - брадикардія, екстрасистолія, зміни зубця $T$ у відведенні aVF.

Таким чином, своєчасне встановлення діагнозу «дифтерія» набуває особливого значення, і він повинен базуватися на даних клінічних симптомів. При підозрі на дифтерію слід враховувати дані епідеміологічного анамнезу, особливо відомості про щеплення в минулому, і тільки своєчасне бактеріологічне обстеження $є$ верифікуючим у встановленні діагнозу. Забір і транспортування матеріалу для бактеріологічних досліджень при підозрі на дифтерію має проводитися у перші 3-4 год з моменту звернення хворого в лікувальний заклад. При лікуванні антибіотиками контрольне обстеження слід проводити через 3 дні після завершення курсу антибіотикотерапії.

Аналіз захворюваності на дифтерію в Україні, починаючи з 1990 р., демонструє її виражену мінливість та зв'язок і взаємодію як соціальних, так і природних факторів, які впливають на проявлення і розвиток епідемічного процесу. Виникнення спалаху дифтерії свідчить про порушення охоплення щепленням населення як дітей, так і дорослих. Збудник дифтерії не зникі циркулює серед населення, тому однією з головних умов ефективної боротьби з дифтерією є активна вакцинація та ревакцинація населення i, зрозуміло, покращення якості життя. Низький рівень імунітету серед контингенту, що підлягав вакцинації, пояснюється тим, що 50\% дітей, народжених у 1985-1988 рр., отримали первинний вакцинальний комплекс АКДП-М та АДС-М анатоксинами без обґрунтування (така вакцина придатна для щеплення хворих та ослаблених дітей). Також у записах вказано про порушення термінів у первинному вакцинальному комплексі. Частина дітей не отримали відповідної вікової ревакцинації. Даних щодо контролю напруженості імунітету серед дорослих на сьогодні не існує.

Різке зниження імунного прошарку як серед дітей, так і серед дорослих, дає активацію циркуляції збудника дифтерії серед населення. Низька якість діагностики, несвоєчасна госпіталізація знижують ефективність протидифтерійної сироватки і підвищують ризик розвитку ускладнень хвороби

Успіх при лікуванні токсичних форм дифтерії передусім залежить від часу госпіталізації та початку лікування. Керована дифтерія, яка раптово стає некерованою, означає неможливість повної ліквідації захворювання. Ліквідувати спалах необхідно і можливо, але побороти збудник неможливо. Раптовий спалах дифтерії у дорослих сигналізує про неблагополуччя в діяльност системи лікувально-діагностичних закладів країни.

\section{Список використаної літератури}

Анастасій І.А. (2017) Особливості перебігу дифтерії в сучасних умовах Акт. инфектол., 5(1): http://www.mif-ua.com/archive/article/44383.

Всемирная организация здравоохранения (2018) Дифтерия (https:// www.who.int/immunization/monitoring surveillance/burden/vpd/04 WHO Surveill anceVaccinePreventable_04_Diphtheria_Russian_R1.pdf).
Мороз Л.В. (1997) Изучение гуморального иммунитета населения Украины к кори и дифтерии как основа эпидемиологического надзора за этими инфекциями. Дис. ... канд. мед. наук, Киев, 148 с.

Центр громадського здоров'я М03 України (2020) Дифтерія (https:// phc.org.ua/kontrol-zakhvoryuvan/inshi-infekciyni-zakhvoryuvannya/difteriya).

American Academy of Pediatrics (2009) Red book (https://redbook.solutions.aap.org/redbook.aspx).

Nekrassova L.S., Chudnaya L.M., Marievski V.F. et al. (2000) Epidemic Diphtheria in Ukraine, 1991-1997. J. Inf. Dis., 181 (Suppl. 1): 35-40.

\section{Клинико-эпидемиологические особенности вспышки дифтерии среди иностранных студентов Ужгородского национального университета \\ С.М. Туряница, И.Ю. Пикина}

Резюме. Снижение поствакцинального иммунитета против дифтерии у взрослых, обусловленного невыполнением ревакцинации наряду с отсутствием соответствующей настороженности, привели к тому, что дифтерия вновь стала актуальной проблемой. В статье представлены данные об эпидемии дифтерии 1990-х годов в Украине. В этот период эпидемическую ситуацию по дифтерии отмечали во всех независимых республиках бывшего СССР, смертность при этом составила 3-23\%. Дифтерия остается эндемической болезнью на этих территориях, а также в странах Азии, Ближнего Востока, Африки, Латинской Америки, где уровень охвата населения прививками с помощью вакцин, содержащих дифтерийный токсин, ниже оптимального. Приведен пример вспышки заболевания среди 15 иностранных студентов Ужгородского национального университета в октябре 2019 г. Проанализировано современное состояние проблемы, приведены основные принципы контроля над вспышками дифтерии.

Ключевые слова: дифтерия, вспышка дифтерии, эпидемия дифтерии в Украине, вакцинация против дифтерии.

\section{Clinical and epidemiological features of the diphtheria outbreak among foreign students of Uzhgorod National University \\ S.M. Turyanitsya, I.Yu. Pikina}

Summary. Decreased post-vaccination immunity against diphtheria in adults due to non-revaccination, along with a lack of vigilance, has led to the fact that diphtheria has again become an urgent problem. The article presents data on the diphtheria epidemic of the 1990s in Ukraine. During this period, the diphtheria epidemic situation was observed in all independent republics of the former USSR, with a mortality rate of 3-23\%. Diphtheria remains an endemic disease in these countries, as well as in Asia, the Middle East, Africa, and Latin America, where vaccination coverage with diphtheria toxin vaccines is below optimal. An example of an outbreak of the disease among 15 foreign students of Uzhhorod National University in October 2019 is given. The current state of the problem is analyzed, the basic principles of control over diphtheria outbreaks are given.

Key words: diphtheria, diphtheria outbreak, epidemic diphtheria in Ukraine, diphtheria vaccination.

\section{Адреса для листування:}

Пікіна Ірина Юріївна

88000 , м. Ужгород, пл. Народна, 3

ДВНЗ «Ужгородський національний університет»,

факультет післядипломної освіти

та доуніверситетської підготовки

E-mail: ira bokshan@ukr.net

Одержано 21.09.2020 